\title{
COVID-19 pandemic: Virtual technology applied to higher education at CU UAEM Valle de México and Ecatepec
}

\section{COVID-19 pandemia: Tecnología virtual aplicada a la educación superior en los Centros Universitarios UAEM Valle de México y Ecatepec}

\author{
RUIZ-REYNOSO, Adriana Mercedes $\dagger^{* 1}$, RAMÍREZ-CORTES, Verónica ${ }^{1}$ and HERRERA- \\ HERNÁNDEZ, Héctor ${ }^{2}$
}

${ }^{1}$ Universidad Autónoma del Estado de México, México, Centro Universitario UAEM ${ }_{E X}$ Valle de México

${ }^{2}$ Universidad Autónoma del Estado de México, México, Centro Universitario UAEM ${ }_{E X}$ Valle de Teotihuacán

ID $1^{\text {st }}$ Autor: Adriana Mercedes, Ruiz-Reynoso / ORC ID: 0000-0002-0353-8493

ID $1^{\text {st }}$ Co-author: Verónica, Ramírez-Cortes / ORC ID: 0000-0001-6541-6769

ID $2^{\text {nd }}$ Co-author: Héctor, Herrera-Hernández / ORC ID: 0000-0002-1485-3624

DOI: $10.35429 / J U P .2021 .14 .5 .19 .27$

Received July 10, 2021; Accepted September 28, 2021

\begin{abstract}
One of the most important challenges in the education system are the technological advances in the educational models at a higher education, achieving a transformation of the student's thinking, in an approach of analysis and innovative construction based on interdisciplinary processes and creativity. The Autonomous University of the State of Mexico is aware that its teachers must have a comprehensive training in communication and creativity with a social and humanistic commitment with transcendence of technological research. Due to COVID-19, pandemic caused by an infectious virus that produced a total closure of educational facilities, in which the only teaching alternative is online, this technology has been integrated by necessity to the educational system with a different pedagogical approach, which has been questioned by the type of knowledge acquired by students. Finally, this research awareness among the teachers of Valle de México and Ecatepec that they must face the challenges in the use of virtual technology.
\end{abstract}

Virtual Technology, Creativity and Education

\begin{abstract}
Resumen
Uno de los retos más importantes en el sistema educativo es el conjunto de los avances tecnológicos en los modelos educativos a nivel superior, logrando favorecer una transformación del pensamiento del estudiante, en un enfoque de análisis y de construcción innovadora fundamentando procesos interdisciplinarios y de creatividad. En este sentido, Universidad del Estado de México (UAEM), es consciente de que sus Docentes deben tener una formación integral en la comunicación y en la creatividad con un compromiso social y humanístico con trascendencia de investigación tecnológica. Debido al COVID-19, pandemia causada por un virus infeccioso que produjo un cierre total de instalaciones educativas, en el que la única alternativa de enseñanza es a través de sistemas digitales, de este modo la tecnología se ha integrado por necesidad al sector educativo con un enfoque pedagógico diferente, del cual ha sido cuestionado por el tipo de conocimiento adquirido por los estudiantes. Finalmente, el sentido de esta investigación es concientizar a los docentes de dos centros universitarios de la UAEM Valle de México y Ecatepec que deben afrontar los desafíos en el uso de la tecnología virtual en el aula de clases.
\end{abstract}

Tecnología virtual, Creatividad y Educación

\footnotetext{
Citation: RUIZ-REYNOSO, Adriana Mercedes, RAMÍREZ-CORTES, Verónica and HERRERA-HERNÁNDEZ, Héctor. COVID-19 pandemic: Virtual technology applied to higher education at CU UAEM Valle de México and Ecatepec. Journal of University Policies. 2021. 5-14: 19-27
}

\footnotetext{
* Correspondence to Author (email: amruizr@uaemex.mx)

$\dagger$ Researcher contributing as first author.
} 


\section{Introduction}

Severe restrictions on the movement of people and rules on physical distancing have now been established, determining social isolation due to the rapid spread of the disease caused by a new coronavirus (COVID-19) case that came from Wuhan, Hubei Province of China. That since 11 March was declared a pandemic by the WHO (World Health Organization) (A Urresti \& Marcellesi, 2012), as a prevention measure for the spread of this infectious virus, the Government of Mexico establishes a strict recession of face-to-face educational activities with the slogan STAY SAFE at HOME. In this sense, the digital technology based on-line is the only alternative to still providing the essential public service, such as education among others.

An example of these solutions is the SEP organization (Secretary of Public Education) implemented a teaching \& learning program (HOME LEARNING) that consists of offering virtual classes on television for students enrolled in preschool, first level on basic education and high school, so, Bachelor's students can continue their education according to the SEP scholar schedule. However, other higher-level students take advantage of digital tools, Apps, E-mail, WhatsApp, Digital books, Mobile devices, Internet connection, Online education programs and educational platforms to maintain communication with their teachers and attend their virtual classes.

Thus, today digital technologies have been considered an essential for higher education students, therefore the present research focuses on two University Centers belonging to UAEM, the Valle de México and Ecatepec, which require a qualitative study that evaluated and identified the use of creativity that teachers and students commonly employ in virtual environments through new generation mobile devices. This will allow the teachers to know and search for the different capabilities of a virtual class using digital technology with respect to a traditional classroom, thus creating a transformation strategy in competencies and skills, whether group and individual to solve any professional or academic problem inside and outside the classroom.
Therefore, it is important to deduce that the teacher must corroborate, enrich, and approach the teaching practice in a mediating way with skills of cooperation, integration and empathy with students using creativity and innovation in the classroom all the time. In this way, it is assumed that the teacher's job is to seek an innovative approach to the design of his teaching with the support of students who use digital technology to integrate the contents in virtual environments or support materials that help reflection and practical and theoretical analysis with different teaching and learning strategies, that comprehensively supports the evaluation of the knowledge acquired by students of higher education.

\section{Methods and description}

This qualitative research is based on a method of data collection and analysis to obtain information from students and teachers in order to quantify the research problem if creativity is the result of innovative strategies applied to the teaching-learning process, which has caused the globalization of learning in an immediate sequence of transformation of competencies and skills of students and teachers.

The sample population of data considered in this study is around 546 students of higher-level education distributed in different semesters of two University Centers belonging to the Autonomous University of the State of Mexico UAEM, as shown in Table 1, CU of Valle de México and CU of Ecatepec.

\begin{tabular}{|l|l|c|}
\hline \multicolumn{1}{|c|}{$\begin{array}{c}\text { University } \\
\text { Center }\end{array}$} & Accounting & 85 \\
\hline \multirow{4}{*}{ Valle de México } & $\begin{array}{l}\text { Administrative } \\
\text { informatics }\end{array}$ & 50 \\
\cline { 2 - 3 } & Administration & 157 \\
\hline Total & Accounting & 292 \\
\hline \multirow{4}{*}{ Ecatepec } & $\begin{array}{l}\text { Administrative } \\
\text { informatics }\end{array}$ & 124 \\
\cline { 2 - 3 } & Administration & 129 \\
\hline Total & & 1 \\
\hline Total & & 254 \\
\hline
\end{tabular}

Table 1 Sample size of data collected from two UAEM University Centers

Source of Reference: Own Elaboration 
As indicated in Table 1, the groups were randomly chosen for each University Center in the period 2021-A (February to July), so the UAEM Valle de México University Center has $53.2 \%$ of surveys answered and $46.8 \%$ corresponds to the UAEM Ecatepec University Center.

Six variables will be studied that will help identify the behavior of the teacher in the virtual classroom in the use of creativity and technology, allowing the improvement of the teacher in a cooperative, constructivist learning, mediator of the teaching-learning process, as well as the professional competences of the teacher. Students and teachers will have developed the following skills and competencies:

1. Creativity and innovation, using mobile devices in virtual environments.

2. Communication and collaboration, use of virtual environments that allow ideal communication and information such as videoconferencing to interact with other students online, work collaboratively, include online work to support individual and collective learning, as well as having the link of students with other cultures.

3. Research and information management, this implies the use of technological tools that allow the student to collect, select, analyze, evaluate, or use the information that the teacher is requesting in the classroom, as well as process the data and communicate the results of an investigation.

4. Critical thinking, problem solving and decision making, students were required to develop critical thinking skills to plan, organize and solve problems and decision-making of work and professional life using mobile devices.

5. Digital citizenship, this one refers to the student understanding the human, cultural and social issues related to mobile device technologies and the application of ethical, legal, safe, and responsible conduct of use.
6. Operation and concepts of mobile device technologies, involves the understanding of concepts related to environments, systems, and operation to select and use productively, as well as transmit knowledge of learning new technologies to apply them in professional and working life.

\section{Results}

The methodology is to develop the skills and attitudes to generate new scenarios with thoughts of reflection, practical and theoretical and innovative and creative, in the use of technology in the classroom that allow to break the rigid paradigm of the teacher providing in a simple way different way of seeing the situations within the teaching-learning process without losing the knowledge that you want to teach.

The author Gilda Walsburd (2009) reflects that commitment is the path of transformation and this path begins when the person is aware of his negativity and how this can be transformed into a creative energy; that is why the teacher must change paradigms and reengineer himself to strengthen in a positive way, creative and constructivist the way to give their class in the classroom, looking for the balance and mental health of the teacher and the student so that the process is easy and worth the search for technological tools to make innovative and creative changes inside and outside the classroom. In this sense, Figure 1 indicates a new reengineering of the teacher to develop innovative didactic strategies with commitment to a new creative and innovative scenario.

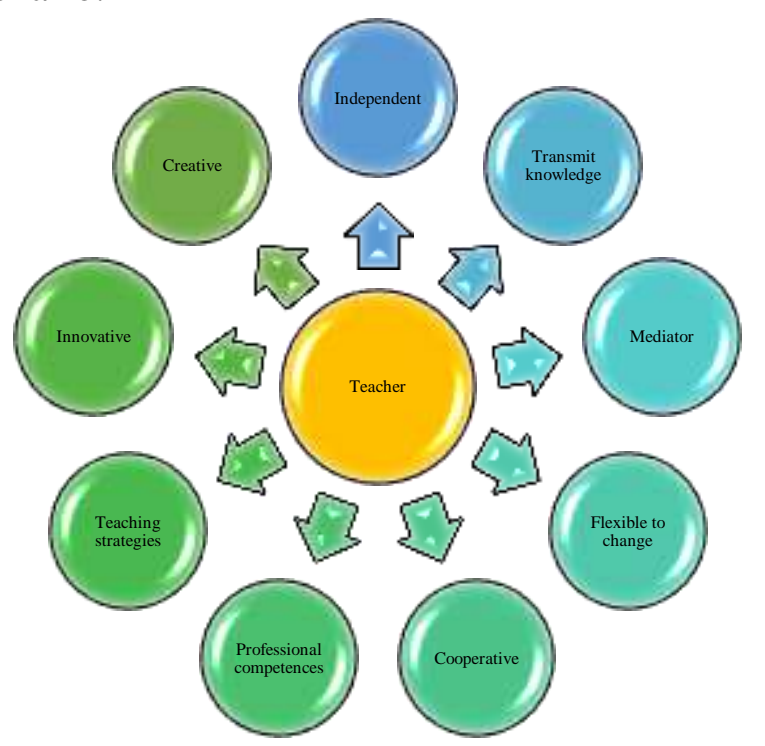

Figure 1 Breaking paradigms Source of Reference: Own Elaboration

RUIZ-REYNOSO, Adriana Mercedes, RAMÍREZ-CORTES, Verónica and HERRERA-HERNÁNDEZ, Héctor. COVID-19 pandemic: Virtual technology applied to higher education at CU UAEM Valle de México and Ecatepec. Journal of University Policies. 2021 
Creativity is important in everyone who can emerge and express or develop when he is in a balance between cognitive-intellectual growth and effective-emotional growth since currently the teacher has implemented strategies in a positive and constructive way in the classroom with the use of virtual environments and mobile devices.

The techniques or strategies are accompanied by a theoretical framework and experiences that interact with each other, to train self-taught professional students in industry and organization. As author Francisco Menchen Bellon says (2009), creativity is like electricity, it's always there, but it needs to connect and ignite and sometimes producing the powerful current takes time. However, creating does not mean doing from anything, but is using the material available and consuming it according to original schemes (Menchen Bellon, 2009).

It is said that innovation is a process of gradual transformation that is developing step by step, currently education has had innovative changes that allow to prepare the teacher-student in the teaching-learning process for continuous improvement.

That is why teaching learning using virtual environments and creativity will allow you to know how to learn, how to dedicate your time and effort to learn and facilitate your learning, this is becoming the property of the university of this XXl century. As can be seen in Table 2, the renewal and innovation of the university in a process of change is indicated.

\begin{tabular}{|l|l|}
\hline $\begin{array}{l}\text { Individually using TICs } \\
\text { to use traditional } \\
\text { methods. }\end{array}$ & $\begin{array}{l}\text { Normal changes of virtual } \\
\text { environments. but without } \\
\text { pedagogical transformation, } \\
\text { The teacher does not } \\
\text { tithout changes of attitude } \\
\text { or procedure. } \\
\text { potential of TICs }\end{array}$ \\
\hline $\begin{array}{l}\text { Individual use of TICs } \\
\text { to update training: } \\
\text { renewal of the teaching } \\
\text { role, the role of } \\
\text { students, and the } \\
\text { methodology. Teachers } \\
\text { emphasis on the student, on } \\
\text { learning innovate on their } \\
\text { procedures, and attitudes; } \\
\text { also, in the acquisition of } \\
\text { skills. Holistic teaching } \\
\text { innovation by faculties or } \\
\text { institutions. }\end{array}$ \\
\hline
\end{tabular}

Table 2 Renewal and innovation in the university of the XXl century

Source of Reference: (Guillermo, 2016)
In this way a virtual teaching-learning environment (VLE) is a set of computers and telematic facilities for communication and information exchange in which teaching and learning processes are developed, the Valle de México and Ecatepec University Centers are in a process of change such as planning, development, the monitoring, and evaluation of training in a virtual environment.

As a result of this research with students they have acquired skills and competencies to manage virtual environments, such as their own learning, being proactive, autonomous, fulfilling their own goals and above all the reflection of their own skills in a reflection of their reflective and critical learning, as well as a collaborative work in the classroom. The competent student must have the communicative skills, such as knowing how to write, know how to structure and know how to know to organize their ideas and correctly handle technology in their professional life.

It is important to mention that the Ecatepec University Center students supported the teachers in the development of virtual learning environments provided different tools that allowed the teacher to perform his function in the virtual classroom, which was a mediator, independent and integrative fulfilling the competencies and the objective of the learning unit. The teacher used tools such as: videos, forums, podcast, apps and carried out an agenda of activities that allowed the participation of the teacher and the student in a cooperative, practical way allowing to have real cases and put into practice the knowledge in a virtual environment.

Likewise, in the question the teacher and the student use in the virtual classrooms the mobile devices to teach their class and the students to develop the activities entrusted by the teacher. However, it was observed that $18.41 \%$ of students indicate that the teacher only teaches the class without using technological tools, so the teacher is not developing the skills and competencies necessary to solve any professional problem. It is important to indicate that creativity is an attitude of life, that teachersstudents must commit to creating a transformation in the classroom with the use of virtual environments so that there is motivation and enthusiasm to have the right learning for each subject. 
It was detected that students perform their jobs better and the willingness to carry out the activities in a collaborative and creative way has improved because they feel motivated in the use of technologies to express their knowledge. The result is the following question: Do you feel motivated to use digital tools in virtual environments to carry out academic activities? As can be seen in Table 5, students have developed the technological skills to implement them in their professional lives.

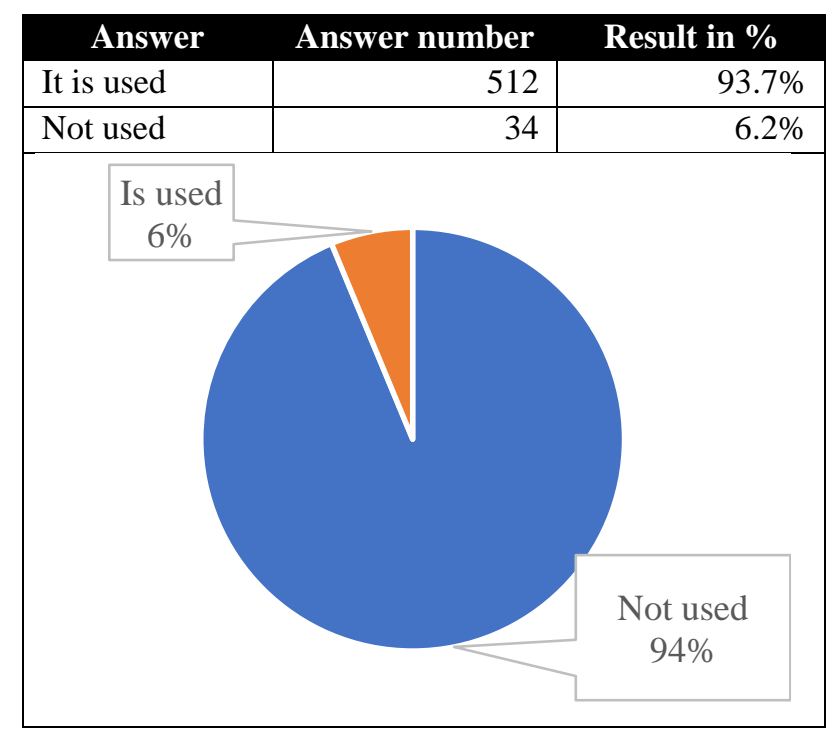

Table 3 Percentage of the use of creativity of teachers and students in academic activities

Source of reference: Own Elaboration

Likewise, students were asked if teachers use technological tools to teach their class?. The result of this question $23.4 \%$ of teachers use technological tools and $76.6 \%$ only used Microsoft Teams, Google MEET and ZOOM for communication, the teacher must be aware of the role he plays in the group, we know that he is exposed to criticism or admiration.

The VLEs provide different tools that give technological support to the measure of the teacher, but it will depend on the skills and competence that he must promote a virtual environment in the classrooms.

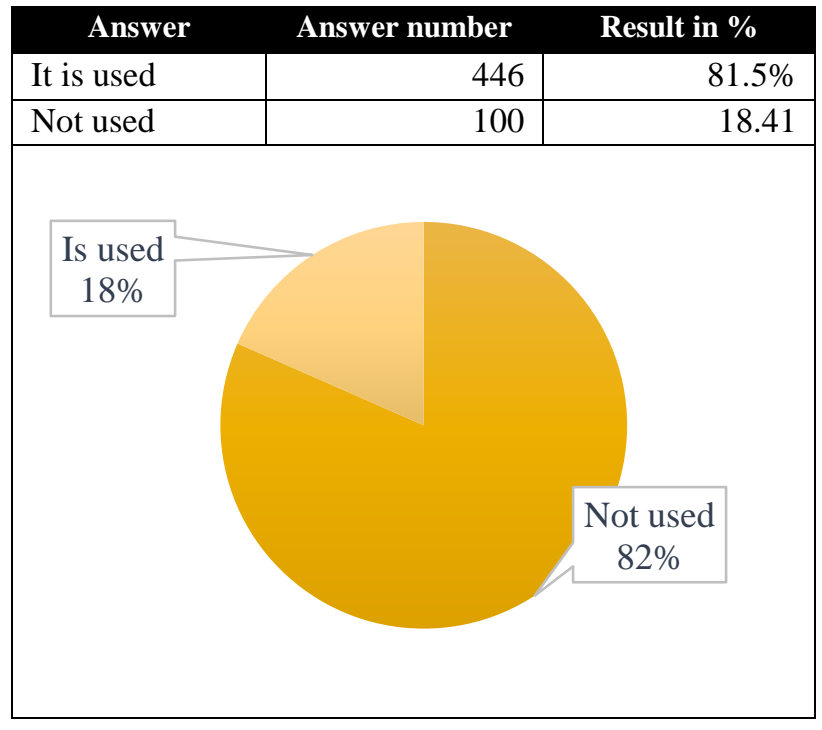

Table 4 Percentage of students using technology in the classroom

Source of reference: Own elaboration

The teacher must meet the objective established in the didactic planning, the function of creativity is the design and development of activities that allow the teacher to evaluate the knowledge acquired according to the teaching process. The teaching process must have creativity on mobile devices, it cannot be explained only as a conscious, artistic or scientific process, as author Menchen Bellon says that you need to daydream, relax, allow the mind to extend to create new proposals that include multiple resources in virtual environments with emerging topics, current discussions and innovative ideas allowing the student to develop competencies and skills to solve any professional and work problem.

That is why the didactic elements of virtual environments with mobile devices must focus on a diagnosis, planning and evaluation during the reorganization and monitoring of the different methodological changes to teach the class online, that is, from a strategy and with technological resources they will form a didactic so that the teacher has a specific didactic for his subject. It is recommended to use a diagram that allows the exchange of creativity and technology in the classroom, as shown in Figure 2 below, shows how the teacher can support students to work collaboratively. 


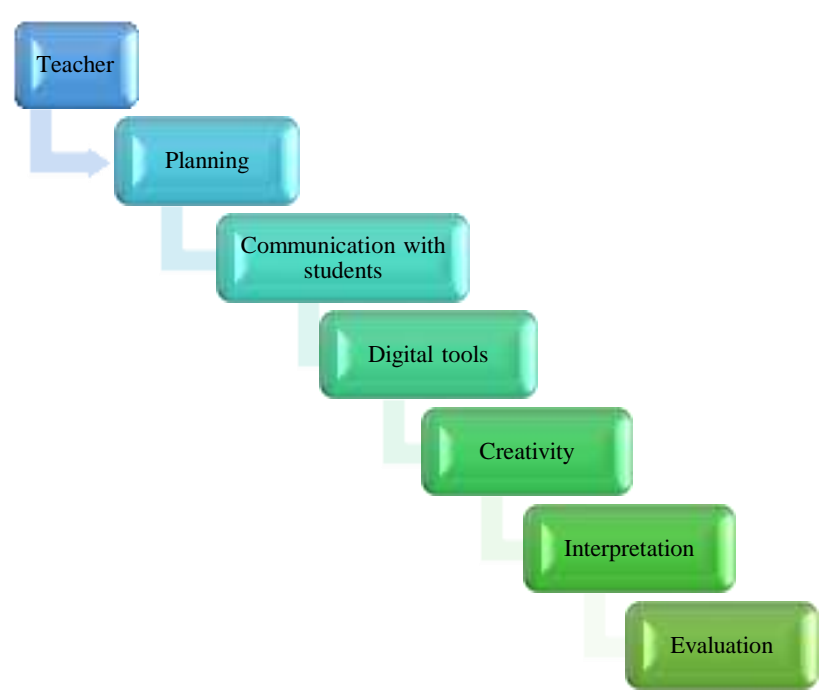

Figure 2 Support model with the student Source of reference: Own Elaboration

The incorporation of technology and creativity will depend on the following important aspects for the teacher:

1. Training: the success of this is that the teacher who must be trained in the use of TICs to be able to teach, which implies designing, developing the course with the necessary materials to present them in the following modalities: face-to-face, mixed and distance. Likewise, students must be able to use TICs for their learning and produce didactic materials for the same purpose. You must also have the authorship of the institution of the materials that will be developed in order to have your own authorship.

2. Infrastructure and equipment: it is a necessary condition for the teacher to achieve an incorporation of TICs in the classroom.

3. There must be virtual teacher tutoring that allows stimulating participation inside and outside the classroom to free functions such as academic performance from which you must learn to respond virtually.

It must have the following functions:

1. Make sure you understand how it works.

2. Give academic advice.

3. Carry out formal activities of integration, communication, and creativity.

4. Stay in touch with the teacher and the student.

5. Support the student in virtual environments for their learning.
6. Gesture self-learning groups.

7. Work on social networks in the classroom as:

a. Facebook: which allows the creation of private groups to share content, create surveys and plan activities.

b. Whatsapp: it serves to form groups or subjects, solve doubts and give notices.

c. Tiktok: allows you to create videos in class and the transmission is direct.

That is why the tutor-teacher must have the skills and attitudes as seen in Figure 3.

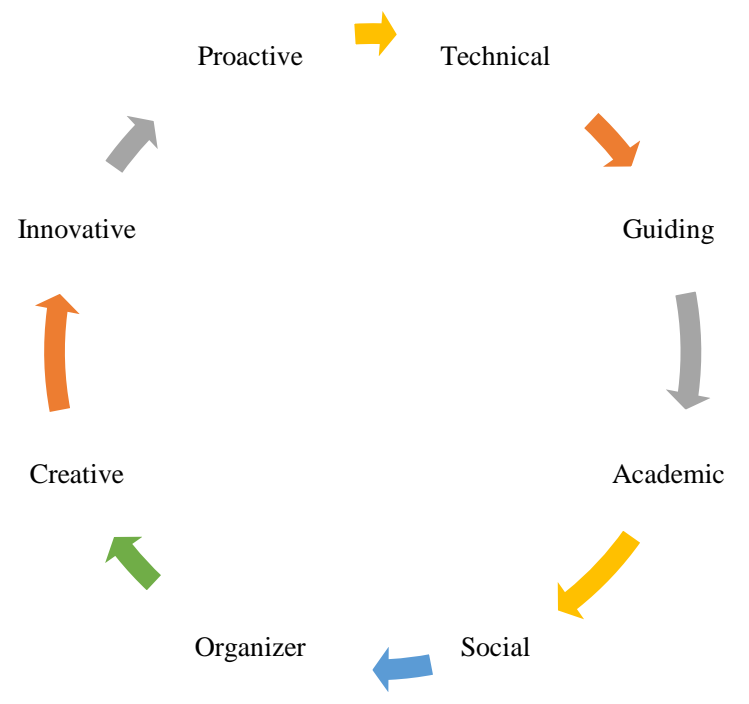

Figure 3 The skills and attitudes of the teacher-tutor Source of Reference: Own Elaboration

This will cause students to be proactive and able to learn and transform what they have learned to meet the needs of the digital age. The elements that make up a creative organization in the classroom, as shown in Figure 4, the awakening to a new knowledge that stimulates creativity, innovation to new skills and abilities, creating a society open to change capable of undertaking and responding to all professional and labor needs.

Technological creativity in the virtual classroom for the teaching of academic education, as author Waisburd Gilda says in the book Creativity and transformation Theory and technique indicates, (Waisburd, 2012), that the process of creative recovery consists of different stages, which appear simultaneously, or some stages before others, which depends on each person (student-teacher) or their personal moment. 
When starting this research with the university centers it was thought that it would be in the same situation of the management of creativity with mobile devices in virtual environments in front of the classrooms, the teacher must generate strategies to promote and improve creativity, so that the student has the ability to reflect and analyze their own personal processes, is shown in Table 5,

\begin{tabular}{|l|l|l|}
\hline P & $\begin{array}{l}\text { Permanent } \\
\text { quality }\end{array}$ & $\begin{array}{l}\text { Quality is a direct, independent } \\
\text { experience that predates any } \\
\text { intellectual abstraction. }\end{array}$ \\
\hline $\mathrm{S}$ & $\begin{array}{l}\text { Shared } \\
\text { enthusiasm }\end{array}$ & $\begin{array}{l}\text { It is the sense of emotional } \\
\text { intelligence incorporating to the } \\
\text { members the value of feeling and } \\
\text { emotion. }\end{array}$ \\
\hline $\mathrm{N}$ & $\begin{array}{l}\text { New } \\
\text { technologies }\end{array}$ & $\begin{array}{l}\text { It is the society connected in a } \\
\text { ubiquitous way and based on } \\
\text { mobility, fundamentally in the } \\
\text { condition of communication and the } \\
\text { active process. }\end{array}$ \\
\hline $\mathrm{W}$ & $\begin{array}{l}\text { Work } \\
\text { images }\end{array}$ & $\begin{array}{l}\text { Having photographs of the future, the } \\
\text { vision is a dream that is awake. }\end{array}$ \\
\hline $\mathrm{C}$ & $\begin{array}{l}\text { Continuous } \\
\text { renewal. }\end{array}$ & $\begin{array}{l}\text { It is a change of dimension and speed } \\
\text { without any origin in history. }\end{array}$ \\
\hline $\mathrm{O}$ & Objectives & $\begin{array}{l}\text { It is an effective way to stimulate the } \\
\text { process and help a long-term vision. }\end{array}$ \\
\hline
\end{tabular}

Figure 4 Elements that compose and can be used in the classroom

Source of Reference: Menchen Beelon, Francisco, La creatividad y las nuevas tecnologías en las organizaciones, editorial edición Diaz de santos, s.a.

When starting this research with university centers it was thought that it would be in the same situation of managing creativity with mobile devices in virtual environments in front of the classrooms, the teacher must generate strategies to promote and improve creativity, so that the student has the ability to reflect and analyze their own personal processes.

\begin{tabular}{|c|c|c|}
\hline Concepts & $\begin{array}{c}\text { CU } \\
\text { UAEM } \\
\text { VM }\end{array}$ & $\begin{array}{l}\text { CU UAEM } \\
\text { Ecatepec }\end{array}$ \\
\hline Creativity and innovation & $39.10 \%$ & $42.80 \%$ \\
\hline $\begin{array}{lll}2 . & \text { Comunication and } \\
\text { collaboration } & \end{array}$ & $6.90 \%$ & $5.50 \%$ \\
\hline $\begin{array}{l}3 . \quad \text { Research and } \\
\text { management of information }\end{array}$ & $5.40 \%$ & $4.20 \%$ \\
\hline $\begin{array}{l}\text { 4. Critical thinking, problem } \\
\text { solving and decision-making }\end{array}$ & $4.50 \%$ & $3.50 \%$ \\
\hline 5. Digital citizenship & $12.00 \%$ & $15.20 \%$ \\
\hline $\begin{array}{l}\text { 6. How mobile device } \\
\text { technologies work and concepts }\end{array}$ & $32.10 \%$ & $28.80 \%$ \\
\hline Total & $100 \%$ & $100 \%$ \\
\hline
\end{tabular}

Table 5 Comparative result of the two University Centers on the development of technological competences in the two periods $2020 \mathrm{~B}$ and 2021A of the University Center Valle de México and Ecatepec

Source of Reference: Own Elaboration
It is observed in table 5, the results on the capacities that the two University Centers have, but the UAEM Ecatepec University Center have a percentage of $80 \%$ higher than Valle de México, this allows to see that the capacities of the teacher are important to plan their courses of action, in the virtual environments using the creativity of the students, monitor the strategies you use, to evaluate productivity in terms of your students' results, so you have more often the instructions or tasks that help them reflect on their learning.

These two variables: the first Creativity and innovation and the second operation and concepts of mobile device technologies are related to the objectives of the research; the result has not been so favorable because the teacher-student does not develop an adequate planning; first to know about; while the second is to have the ability to do something; the teacher must plan the knowledge that is required to recognize the skills and processes of teachinglearning of which it will be taught, likewise must mold the skills and shape the skills that you want to teach and finally must exchange the knowledge with the students with their own experiences. It is proposed that in the two university centers they develop the content of virtual environments using the creativity of applications on mobile devices to integrate them as a collaborative work between the teacher and the student.

The authors Manuel Flores and Olga Gonzales in their book EL TRABAJO DOCENTE (Flores, 2014) explains a model of constructivist learning environment that must be implemented to improve student learning, five important elements should be used:

- Positive interdependence: Students should think that they are linked to their peers.

Face-to-face interaction: Students should converse with each other and help another with homework.

Individual commitment: Each student must be responsible, in their individual way as a group.

- Social skills: Students should interact with the group appropriately in the learning process. 
- Goal achievement process: The group of students should regularly monitor what they have achieved and reflect on how the group or individual might function more effectively.

Cooperative learning is a good strategy for teaching-learning activities in virtual classrooms; by using this strategy will allow the student to have better knowledge, critical thinking and high metacognitive reasoning using creativity.

\section{Conclusion}

The results obtained in this research show that the two University Center of UAEM Valle de México and that of Ecatepec in the three degrees:

\begin{tabular}{|l|l|}
\hline 1 & Accounting career \\
\hline 2 & Administrative Informatics career \\
\hline 3 & Administration career \\
\hline
\end{tabular}

They show that the indicators of the six variables are not acquiring the knowledge and skills necessary to solve professional problems with the use of mobile devices in virtual environments.

\begin{tabular}{|ll|}
\hline \multicolumn{2}{|c|}{ Indicators } \\
\hline 1. & Creativity and innovation \\
\hline 2. & Communication and collaboration \\
\hline 3. & Research and management of information \\
\hline 4. & Critical thinking, problem solving and decision-making \\
\hline 5. & Digital citizenship \\
\hline 6. & How mobile device technologies work and concepts \\
\hline
\end{tabular}

Both had to have developed the skills and knowledge, which allow the student to excel in any area, these facts lead us to revalue again the skills and abilities since their function of the teacher-student is to generate new knowledge and skills that interact with creativity and mobile devices individually or as a team, make more aware of digital citizenship, as well as the operation and concepts of device technologies that indicate that there is no great difference to be analyzed.

There are some deficiencies that can be used and focused, channeled to guide students, to create critical and innovative thinking in decision-making in the use of devices and finally, there is a limitation in the present work is that when teachers-students return in person they will stop using technological means to teach their classes and will return to the traditional; and of which there will be no innovative change.

\section{Acknowledgement}

Thanks to the Autonomous University of the State of Mexico and UAEM Valle de Mexico and Ecatepec University Centers for their support of the development of this research that allows us to innovate new strategies to be able to teach classes inside and outside of their classrooms.

\section{References}

Abud Belinda, Lujambio Julieta, Educar en la era digital sin perder lo esencial, Editorial Limusa, 2015, México.

Aduriz, Isidro, Arinci Victoria, Chitarroni, Trotta Gamus Elisa y Wermus Naomi, Hacia la inclusión digital, editorial Granica, Mexico,2005

Bautista Guillermo, Borges federico y Flores Anna, Didáctica Universitaria en entornos virtuales de enseñanza -aprendizaje, Editorial Narcea, 2018, España.

Belinda, A. (2018). Educar en la era digital sin perder lo esencial. Limusa.

Chan Núñez María Elena, Entornos Reales Mixtos y virtuales, Universidad de Guadalajara, 2019, México.

Duarte Ayala Roció Elizabeth y Rojas Tinoco Karina, Experiencias educativas compartidas, editorial Newton, 2020, México.

Ferreiro Ramon, Como ser mejor maestro, Método Eli, Editorial Trillas, 2019, México

Flores Fahara Manuel y González Capetillo Olga, El trabajo Docente, Editorial trillas,2014

Flores, F. M. (2014). El trabajo Docente. México: Trillas.

Guillermo B. (2016). Didáctica Universitaria en entornos virtuales. Madris, España: Alfaomega.

Menchen Bellon, F. (2009). La creatividad y las nuevas tecnologías en las organizaciones modernas. Madrid, España: Ediciones Diaz de Santos, S.A. Obtenido de http:/ediciones.diazdesantos.es 
Mendoza Buenrostro Gabriel, Didáctica; Las nuevas claves de la enseñanza y el aprendizaje, editorial Trillas, 2020, México

Polanco Bueno Rodrigo y Navarro Nájera Brenda, Manual de apoyo para el desarrollo de competencias. Editorial Alfaomega, 2020, México.

Rue Domingo Joan, Entornos de aprendizaje digital y calidad de la educación superior, editorial Pedagogía, 2014, México.

Waisburd, G. (2009). Pensamiento Creativo e Innovación. Revista Digital Universitaria.

Waisburd, G. (2012). Creatividad y transformación teoría y técnica. México edición: Trillas. 